\title{
Capital adequacy and lending and deposit behaviors of conventional and Islamic banks
}

\begin{abstract}
Capital adequacy plays an important role in determining banking activities. A bank must hold a minimum level of capital to ensure sufficient funds to buffer against unexpected losses or adverse shocks. This study analyzes and compares Islamic and conventional banks in 14 Organization of Islamic Conference (OIC) countries from 1999 to 2009. The empirical evidence suggests that capital requirements have a significant impact on the deposit and lending behaviors of the 52 Islamic banks (IBs) and 186 conventional banks (CBs) in the sample. There is a strong positive relationship between capital requirements and deposit and loan growth for both IBs and CBs.
\end{abstract}

Keyword: Capital adequacy ratio; Islamic and conventional banks; Loans and deposits 